\title{
The Constructions of Family Holidays in Young Middle-Class Malaysian Chinese
}

\section{Children}

\begin{abstract}
The absence of children in tourism research has been identified by past scholars but the rising attention on Asian consumers in tourism has also implied that the voices of Chinese children need to be heard. This study triangulates fourteen young Malaysian Chinese children's drawings of their favourite family holidays with open-ended interview questions. The drawings were analysed using the five thematic levels according to a model of analysis of children's drawings. Findings revealed the collectivistic Confucian values of family and education during vacations, but also highlight what Chinese children conceptualised as fun holiday activities. A number of suggestions are provided for future research and for tourism practitioners to provide memorable holiday experiences for their young travellers.
\end{abstract}

Keywords: family tourism, Chinese, Asian, Confucianism, children, drawing, qualitative

\section{Introduction}

Tourism scholars have already begun to highlight the differences between Asian and Western travellers. Asian guests in hotels for example, are not as familiar as non-Asians with complaint channels and are therefore less likely to complain on holidays (Ngai, Heung, Wong, \& Chan, 2007). When compared to Americans, Asians are more forgiving of hotel service failures (Ekiz $\& \mathrm{Au}, 2011)$ but expect a higher standard of service quality than their Western counterparts (Reisinger \& Turner, 2002). Further, Reisinger and Turner (2002) found significant differences 
between Australian and Asians in the tourism industry. More specifically, they pointed out that Asians are "very much family oriented...each member of the family depends on the other for security and protection" and that these family ties do not exist amongst Australians (p.305). Evidences for this distinction in holiday behaviours between Asians and Westerners are growing in cross-cultural tourism studies. It has been found that learning, education and the acquisition of knowledge are especially valued by Asian adults during vacations (Ap, 2004; Wong, 1996) and impressed upon their children during family holidays (Khoo-Lattimore, Prayag, \& Cheah, 2015). Empirically, Asian parents have articulated demand for educationalrelated programs that range from swim classes and horse riding to cooking and nature-related programmes for their children at holiday sites, including accommodation (Khoo-Lattimore et al., 2015).

Given that research on family tourism is only limited (Carr, 2011; Poria \& Timothy, 2014; Schänzel, Yeoman, \& Backer, 2012), and studies on Asian families less so (Kim, Choi, Agrusa, Wang, \& Kim, 2010; Wang, Hsieh, Yeh, \& Tsai, 2004), our understanding about Asian children on holidays is far from advanced. This study therefore aims to fill this gap by exploring the holiday experiences of young Malaysian Chinese children, by listening to their voices through a child-led research method. By doing so, this paper makes a contribution to the family tourism literature by identifying variables and constructs from some of the youngest members of families. By focussing on Chinese families, the findings will contribute to our theoretical understanding on meanings of holidays for Asian families. The rest of this paper presents a critique of current tourism and hospitality research on children. In doing so, it also highlights the potential influences of the Confucian value of 'family' (inherent in many Chinese communities) on how Chinese people experience family holidays. The methodology for the study is then explained, before the key findings are presented and discussed. 


\section{Literature Review}

\section{Children in tourism}

Existing studies often fail to recognize that young children are social actors that influence the vacation experience of their families (Schänzel et al., 2012). This could be due in part to the assumption that older children hold a stronger influence in their family holiday decisionmaking and younger children exert limited, if any, authority. A literature review of tourism studies involving children revealed that data for family tourism research has been mostly collected from only parents (see for examples, Chen, Lehto, Behnke, \& Tang, 2015; Howard \& Madrigal, 1990; Khoo-Lattimore et al., 2015; Lehto, Choi, Lin, \& MacDermid, 2009; Lugosi, Robinson, Golubovskaya, \& Foley, 2016; Segumpan, Zahari, \& Jamaluddin, 2008; Thornton, Shaw, \& Williams, 1997; Turley, 2001) or adult caregivers (Gaines, Hubbard, Witte, \& O'Neill, 2004). The omission of children as sample is problematic in that it limits our knowledge of how children experience holidays, what they need, and if they would like to holiday differently from their parents. As the dearth of children's voices has been highlighted, scholars have started to involve children in family tourism research. Table 1 summarises existing studies that have done so and highlight three significant observations.

\section{(Insert Table 1)}

Firstly, the majority of the children involved are older, typically of school age and commonly adolescents. Gram (2005) and Therkelsen (2010) were working off the same dataset (Gram \& Therkelsen, 2003) and although children as young as 0 were involved, "interviews were conducted without any significant input from children" (Therkelsen, 2010, p. 771). It can be derived from the literature that the youngest children interviewed are five (Hilbrecht, Shaw, 
Delamere, \& Havitz, 2008) and six (Schänzel, 2012) years old. These scholars who have worked with younger children have reported problems in their attempts to extract quality data (Hilbrecht et al., 2008; Schänzel \& Smith, 2014). Khoo-Lattimore (2015) attributes these difficulties and the prevalent absence of young children's voices to methodological challenges and outlined five considerations when researching young children.

A second observation is the persistent theme that children have their own opinions and ideals about what constitutes a good holiday, which differ from those of their parents. Carr (2006) highlights this contrast with a 13-year old female respondent and her parent in his study - while she described her perfect holiday as staying in a Hollywood motel with her friends, going to the beach, shopping, visiting theme parks and visiting celebrities, her mother described their ideal holiday as having a huge church gathering of friends and family in Broomshead, Australia with the children undertaking lots of beach activities. Dissimilarities such as this between children and parents were also emphasized by six other studies (Blichfeldt, Pedersen, Johansen, \& Hansen, 2011; Gram, 2007; Hilbrecht et al., 2008; Nickerson \& Jurowski, 2001; Schänzel, 2012) but given that they focus on older children, insights into younger children's holiday ideals are missing.

Finally and more surprisingly, only one research was conducted on Asian children (Liang, 2013). Liang (2013) found that Taiwanese teenagers have significant influence on their parents in the context of purchasing tourism products online. Despite the growing research on Asia (Mura \& Pahlevan Sharif, 2015), and on China, we still do not have enough data on what Chinese children want from their holidays, what family vacations mean for them, and how they would like to experience leisure travel. Given that travel attitudes and behaviours developed in the early years have impacts on travel consumption behaviours in later life (Small, 2008; Todd 
Weaver, Moschis, \& Davis, 2011), and coupled with the growing number of Chinese travellers as one of the largest tourism markets for the world (UNWTO, 2016), it is critical that tourism marketing scholars identify and/or strengthen new and existing frameworks and theories for understanding Chinese children.

\section{Chinese children in family tourism}

Although it has been established that the Chinese market is heterogeneous (Khoo-Lattimore, Yang, \& Lai, 2016; Weaver et al., 2015), Confucian values characterize and explain behaviours observed in many Chinese societies (Yang, Khoo-Lattimore, \& Arcodia, 2016), including but not limited to those in Mainland China, Taiwan, Japan, Korea, Hong Kong, Singapore, Indonesia and Malaysia. The influence of Confucianism on Chinese tourist behaviour has been confirmed by many studies (Fu, Cai, \& Lehto, 2015; Kwek \& Lee, 2010; Mok \& DeFranco, 2000; Tse \& Hobson, 2008) but have not included young Chinese tourists per se. For scholars researching family tourism, attention to this exclusion would be worthwhile because the family, in Confucianism, is the prototype of all social organisations (Mok \& DeFranco, 2000). This means that a person is not primarily an individual but rather a member of a family, and so children are taught to suppress their individuality and to conform to the collectivistic goals of the family to maintain the harmony.

Confucian values were alluded to in Khoo-Lattimore et al. (2015)'s study on Asian family tourism - their findings revealed that Malaysian Chinese parents discussed their preferences for educational activities at the holiday destination and accommodation - but the study collected data only from the mothers and not children. Therefore, although the literature acknowledges that Confucian values teach children to be polite to their seniors, respect their teachers and 
tolerate injustice (Hsieh \& Scammon, 2015), the impacts of these values on how young Chinese children respond to family holidays are not yet known. We also know that subordination and harmony through hierarchical arrangements are key principals within Confucian values (Hsieh \& Scammon, 2015) and that Chinese children influenced by Confucian values, "tend to be more respective and receptive to their parents' arrangements in their daily lives in order to maintain harmony and the hierarchical relationship" (Lee, Wong, \& Brown, 2015, p. 214). However, our knowledge of how and whether these values translate into travel behaviour remains absent. We also recognise that Asian parents emphasize the value of education even during leisure and when on holidays but whether or not their children conform as prescribed by their Confucian teachings, or have different opinions like Western children do, warrants further investigation. The aim of this study therefore is to address these gaps on Chinese children in family tourism research and asks the questions of how young Chinese children experience family holidays, and how they define fun. Underpinned by Confucianism, this study conceptually explores the reconstruction of family tourism through young children (whose voices remain marginal in tourism), and addresses the increasing call to shift discussions away from Eurocentric theories of travel consumption.

\section{Methodology}

\section{Sampling}

In order to address the gap on younger-aged children in existing family tourism research, this study will attempt to collect data from as young a child as possible. The literature provides some guidelines, and recommends five and six year olds as the most suitable youngest candidates for interviews or surveys because they are able to work on a task for more than an hour (Ruff \& Lawson, 1990), capable of recalling autobiographical memories (Fivush \& Hamond, 1990), and can express their thoughts on complex issues such as family conflicts 
(Gross \& Hayne, 1998). As such, the respondents for this study were sought from a private primary school in Malaysia. More specifically, students from its preschool classes were selected for this study because their ages (five and six) match those recommended by the literature. The help of class teachers was sought to hand-pick those who are more proficient in their language skills, and consent was sought from the students' parents through the school. Eighteen students were nominated but only fourteen of whom were Chinese were included in this study. Although school fees for private schools are comparatively more expensive than public schools in Malaysia, not all parents of the children who attend them are necessarily wealthy. Many middle-class families, particularly Chinese middle-class families, are increasingly opting for private education for their perceived quality, comprehensiveness and international appeal ("Malaysian Parents Choose International Schools Over National Schools These Days - What Are The Advantages?," 2015). A few private schools in Malaysia do charge exorbitant fees for the elite but the majority of them compete for the larger segment and offer competitive fees for middle-income families. The school selected for this study is a case for the latter.

\section{Data collection method}

Given that the aim and nature of the study are exploratory, a qualitative approach was adopted. Data collection was based on a visual research method. The children were asked to draw a picture of their favourite holiday. Drawing is thought to be most suitable for preschool children as it is an activity that they are most familiar with, and typically enjoy. Barlow, Jolley, and Hallam (2011) argued that because children's spontaneous and self-directed drawings reflect what they are most interested in, drawings are likely to elicit answers as to the most salient episodes associated with the topic of the drawing (p.480). Mitchell (2006) posited that drawings are a tool for engaging children to identify issues that are of interest to them. 
Although the day they were asked to draw and interviewed took place immediately after the school holidays, the students were told that they did not necessarily have to draw their last holiday, only their favourite, and what they felt was the best holiday. The children had access to colour pencils, and effort was made to engage them as they draw by clarifying what they were drawing and why a particular object was meaningful to them. The first child turned in his drawing in six minutes and the last child, after twenty one minutes. The interviews were conducted in a very informal draw-and-tell interactive session. The children's drawings were used as entry points into their thoughts and feelings about family holidays, and carefully selected prompts were used to follow up on their answers. For example, instead of using "why" as prompts, the children were asked to "tell me more about that" on the basis that the use of why questions on pre-schoolers may cause them to feel like that they have to defend their views (Gibson, 2012). The interviews were audio-recorded and then transcribed verbatim.

\section{Data analysis}

The primary data for this study is the children's drawings and these were analysed following the guidelines provided in Kuhn (2003)'s model of analysis of children's drawings. Each drawing was analysed at first for descriptive elements of the personal (e.g. child, parents), natural (e.g. grass, sun), objective (e.g. table, football) and symbolic (e.g. arrow, musical notation). Then, each drawing was evaluated for the location (e.g. classroom), simultaneous social relations (e.g. two people doing two different activities), and together social relations (e.g. two people doing one activity together). These activities were also distinguished as either related to movement or otherwise. Finally, the drawings were analysed using five thematic levels of (a) static display of persons or objects, (b) view of the activity, (c) presentation of a specific event, (d) display of objects admired by the child, and (e) display of abstract values 
which the child has a tendency for. Transcripts from the interviews were used as supplementary, supporting data to the drawings, for the purpose of triangulation.

\section{Findings and Discussion}

All of the drawings contain images typically associated with holidays - blue skies, sun, sea, trees, birds, butterflies and even rainbows. Whether or not these images were deliberately drawn because the children necessarily associated them with holidays cannot be confirmed except for butterflies, which is explained in the section on "Holiday Activities" below. Twelve of the children drew themselves into their pictures of family holidays, and 8 of the twelve drawings included other immediate family members of father, mother and brother, but also extended family members like "Godma" (godmother), "Ma-ma" (grandmother), "Gong Gong (grandfather), "Yi-Yi" (auntie) and even "Kakak" (the domestic maid). The inclusion of these family members does seem to reinforce the collectivistic Confucian value of family but it would be interesting to see if Western children would have drawn their favourite holidays differently. Figure 1 illustrates one of such family holidays. Anthony (pseudonym assumed, as will be for all other respondents reported from hence on) drew himself in black surrounded by seven of his family members, in yellow. The use of colours to single himself out of the group of family members may indicate a desire for individuality, a break away from the teaching of Confucianism but can only be verified through further conversation with Anthony on the subject matter, which was unfortunately not carried out in this study. Anthony's drawing could also be indicative of the emerging rise of intergenerational mobility in the leisure space that scholars have recently highlighted (Kluin \& Lehto, 2012; Murray, 2015; Schänzel \& Yeoman, 2015).

\section{(Insert Figure 1)}




\section{Favourite family destinations}

Twelve of the drawings, and supported by the interview transcript provided information on where young Malaysian Chinese children's favourite holidays took place. Of the twelve, only two was based on nature, one was the beach and another, a park. In the other ten drawings, it was clear that young Asian children's constructions of family holidays are very much associated with themed environments as constructed by tourism corporations. Figures 2, 3 and 4 are examples of how the children's drawings of buildings depict corporate media fantasies such as Hello Kitty theme park, Legoland, Club Med, and Hard Rock Hotel. Other corporate representations, as articulated by the children themselves include the KL Tower, Sentosa Island Singapore and York Hotel Singapore. The names of these holiday sites were easily recalled by children, confirming a recent investigation that at least for the children in this study, "brand recognition and symbolism starts in early childhood and that this brand knowledge may play a role in the development of materialistic tendencies" (Watkins, Aitken, Robertson, Thyne, \& Williams, 2016, p.583).

\section{(Insert Figures 2, 3 and 4)}

On whether these destinations were decided by them, one of the respondents replied, "My daddy chose it", while another proclaimed, "My Mummy and Daddy decided". Even in cases where the children had older siblings of high school years, the decision on where to holiday was made by their parents. The children did not seem to begrudge their parents this decisionmaking however, and one respondent was observed to good-naturedly laughed about how much 
she wanted to go to play with a girl in the hotel's restaurant but, "My mummy don't [won't] let me". Although Khoo-Lattimore et al. (2015) have confirmed the influence of Confucian values on Asian parents on family vacations, the findings in this study reinforce the values of respect for and subordination to parents in young Chinese children where holiday decisions are concerned. This is not to say however that the parents' own decisions on destinations are not also influenced by their children's logistical needs or known wishes.

\section{Fun holiday activities}

Given the strong presence of corporate tourism brands in the children's drawings, it is not surprising that holiday fun for these children include the consumption of manufactured tourism experiences such as swimming in hotel pools (see Figure 5 below), playing on waterslides and jumping on Club Med's trampolines (see Figure 2). Majority of the children talked about swimming pools and when probed on reasons why, a typical answer was one such as Qiao's, "I like the pool because they have a slide". In fact, one child even communicated his "hate" for the swimming pool he was at because it "got no waterslide" and "it's not shallow". For the young Chinese travellers and their families, holiday accommodations which list swimming pool as one of their facilities may not be sufficiently attractive unless they also market a wading pool and/or a water play area.

\section{(Insert Figure 5)}

Four of the drawings contained butterflies, which are nature-based imageries that one would expect to indicate preferences for natural tourism spaces. However, upon further enquiry, the children revealed some more commercial holiday locations and associated activities. For example, one child animatedly described going to the Butterfly Park and chasing after the 
butterflies while another talked about flying a butterfly kite with her sister. In addition, although both activities and especially the Butterfly Park would be deemed educational and chosen by parents for that purpose, none of the children revealed any hint of academic information about butterflies, even upon the researcher's prompts of simple questions such as, what are baby butterflies called, and what do butterflies eat. Given that Asian parents focus on educational activities despite being on holidays (Khoo-Lattimore et al., 2015), touristic sites aimed at families with children could do more to ensure that learning becomes a more tangible value for parents. For example, children could be presented with a picture booklet of educational information related to the site, with activities that children can complete at the site in exchange for a pride badge, medal, trophy or certificate. It is also interesting to note that although commercial tourism advertisements often contain images of families with young children on beaches, only one child in this study described fun as being on the beach and even in this case, the fun element was not the beach but a horse that was on the beach. Similar to the butterflies, horses on Malaysian beaches have been commodified for tourist rides and photographs.

The most surprising finding is the consensus on the children's conceptualisation of 'fun' within their hotel rooms. Children in this study expressed excitement in having baths, in place of showers at home (Malaysian homes do not typically have bathtubs). They were also enthusiastic about connecting rooms and chattered about going in and out of the door between the rooms occupied by them and other family members. They engaged the researcher in animated conversations about jumping on hotel beds and eating cookies and cupcakes in the "bedroom". These elements of holiday fun are not currently common imageries in tourism advertisements. Even parents may not necessarily realise or understand that their children saw more fun in the everyday objects such as bathtubs, beds and doors than deliberated tourism 
activities centred on particular site visits. This finding has never been uncovered in previous research on family tourism. It is also note-worthy that these fun elements were not represented in the children's drawings and only elicited during the interviews.

The findings have thus far highlighted that at least for young Malaysian Chinese children, tourism spaces managed by corporate tourism brands stand out better than those managed by public entities (such as national parks) in their branding and promotion strategies, through the activities they offer that parents are willing to pay for. In destinations where their governments and destination managers are motivated to make parks and public leisure spaces more attractive to its residents and tourists, this finding might provide insights into whether or not public parks and rainforests can compete for a share of the family tourism market, or how they might like to be promoted. For example, accommodation spaces within national parks could be marketed for their bathtubs and bouncy beds. Similarly, natural rainforest canopies could be sold as interconnecting 'rooms' for hiding and running in and out of.

\section{Implications and Conclusion}

By exploring the articulations of the youngest possible members of Malaysian Chinese families on holidays, this study has contributed to the tourism and hospitality literature in two major ways. Firstly, the study recognises that the western notion and meaning of leisure and vacation may not necessarily apply for many Asian families (Khoo-Lattimore et al., 2015). This is timely given the rise of Asian travellers and the associated emerging academic attention on Asians in the tourism industry. For examples, Khoo-Lattimore and Mura (2016) recently published a book addressing the knowledge gaps on Asian genders; Yang, Khoo-Lattimore, and Arcodia (2017) just revealed particular risk-taking travel behaviours of Asian women who travel solo; and Springer has announced a new series of tourism books focussing on the 
“different aspects of Asian tourism and its intricate economic and social-cultural trends...[that] contributes to the idea that tourism, as both phenomenon and field of study, should be more inclusive and disentangled from dominant (mainly Western) ways of knowing” (www. Springer.com/series/15382). This study contributes to the incipient research focus and explicitly considers the expressions of young Chinese children as co-creators of their family holiday experience. By doing so, this study provides a crucial platform for the developments of Asian children in tourism research.

Second, the findings have highlighted the significance of Confucian values and how they play out in the travel behaviour of young Chinese children in Malaysia. Communal characteristics of Confucianism such as respect for, and subordination to older family members were evident in the data but interestingly, traces of individualism also showed up in some of the young respondents. In the increasing call for tourism scholars to decolonise research on and/or by Asians (Mura \& Khoo-Lattimore, 2018; Yang, Lee, \& Khoo-Lattimore, 2018), this study contributes to existing theoretical frameworks investigating Chinese travellers with specific constructs for empirical testing.

Third, the benefits, and reasons for using children's drawings delineated in this study will serve as a guide for future scholars considering the method. The drawings very appropriately served as an entry point to the young children's abilities to express what they want and experience during family holidays. No tourism study thus far has administered this research tool on children as young as five years old but more importantly, the availability of their drawings allowed Chinese children who are typically more reserved and less expressive than Western children, to communicate "something about their family holidays in an alternative, nonlinguistic symbolic language" (Gamradt, 1995, p. 741). Although it is acknowledged that the 
children's experiences can never be objectively and/or completely captured by the researcher, the drawings and the room for the children to talk about their drawings, enables the children to express their family holiday experiences (Poria \& Timothy, 2014; Small, 2008).

Practically, this study provides insights for hotel, resort and destination managers into what young children want from their holidays. Research has already shown that product and brand messages cultivated in childhood have long-lasting effects (Connell, Brucks, \& Nielsen, 2014), and holiday destinations could do well to target young travellers today as their future and repeat guests. This study shows that a number of corporate tourism bodies have been fairly successful in capturing the share of mind of the young Chinese children's market, in that children as young as five years old are able to articulate their brands and associate them with positive experiences. The children's expressions in this study also point to their abilities to understand the meaning of fun, and to retrieve notions of fun-generating products (such as the water slides, bath tubs, and connecting doors) and experiences from their family holidays. The marketing assumptions that underlie this can be significant and have been alluded to the long-term share of heart for businesses. Tourism and even recreation and leisure providers may do well by listening to young children who by the age of five (at least in this study) are able to recognise brands. Holiday experiences should not only be made memorable for their parents but also the young travellers in any family group. Particularly for Asian parents who emphasize the educational value of family holidays, tourism providers need to make the intangible tangible and recommendations for how to do this have been provided in the discussion above.

Finally, the small sample size of the children in this study is acknowledged and future scholars could extend the scale of this study. In addition, the perception and experiences of other Chinese children would make an interesting comparison to those in this study, as would 
whether or not young Western children perceives the same fun in the tourism products expressed by these Malaysian Chinese children. It should also be noted that in this paper, the heterogeneity of Asian and Western travellers has not been elucidated, and future scholars should note the cautions that have been raised in the literature about the potential problems with treating all Asians as a homogenous market segment (Khoo-Lattimore \& Prayag, 2015; March, 1997). Relatedly, this paper has not considered the many debates on the division of epistemologies into 'Western' and non-Western' (for examples, Chambers \& Buzinde, 2015; Mura \& Khoo-Lattimore, 2018; Tucker \& Zhang, 2016) and positioning the paper from this theoretical lens might reveal different findings.

\section{References}

Ap, J. (2004). Intercultural behaviour: Glimpses of leisure from an Asian perspective. In K. Weiermair \& C. Mathies (Eds.), The tourism and leisure industry: Shaping the future (pp. 123-134). New York: Haworth Hospitality Press.

Barlow, C. M., Jolley, R. P., \& Hallam, J. L. (2011). Drawings as memory aids: Optimising the drawing method to facilitate young children's recall. Applied Cognitive Psychology, 25(3), 480-487. doi:10.1002/acp.1716

Blichfeldt, B. S., Pedersen, B. M., Johansen, A., \& Hansen, L. (2011). Tweens on holidays. Insitu decision-making from children's perspective. Scandinavian Journal of Hospitality and Tourism, 11(2), 135-149. doi:10.1080/15022250.2011.588444

Carr, N. (2006). A comparison of adolescents' and parents' holiday motivations and desires. Tourism and Hospitality Research, 6(2), 129-142. doi:10.1057/palgrave.thr.6040051

Carr, N. (2011). Children's and families' holiday experience. Oxon, UK: Routledge.

Chambers, D., \& Buzinde, C. (2015). Tourism and decolonisation: Locating research and self. Annals of Tourism Research, 51, 1-16.

Chen, Y.-S., Lehto, X., Behnke, C., \& Tang, C.-H. (2015). Investigating Children's Role in Family Dining-Out Choices: Evidence From a Casual Dining Restaurant. Journal of Hospitality Marketing \& Management, 1-20. doi:10.1080/19368623.2016.1077368

Connell, P. M., Brucks, M., \& Nielsen, J. H. (2014). How childhood advertising exposure can create biased product evaluations that persist into adulthood. Journal of consumer research, 4l(1), 119-134. doi:10.1086/675218

Ekiz, E. H., \& Au, N. (2011). Comparing Chinese and American attitudes towards complaining. International Journal of Contemporary Hospitality Management, 23(3), 327-343.

Fivush, R., \& Hamond, N. R. (1990). Autobiographical memory across the preschool years: Toward reconceptualizing childhood amnesia. In R. Fivush \& J. Hudson (Eds.), 
Knowing and remembering in young children (pp. 223-248). Cambridge, UK: Cambridge University Press.

Fu, X., Cai, L., \& Lehto, X. (2015). A Confucian analysis of Chinese tourists' motivations. Journal of Travel \& Tourism Marketing, 32(3), 180-198.

Gaines, B. L., Hubbard, S. S., Witte, J. E., \& O'Neill, M. A. (2004). An analysis of children's programs in the hotel and resort industry market segment. International Journal of Hospitality \& Tourism Administration, 5(4), 85-99. doi:10.1300/J149v05n04_05

Gamradt, J. (1995). Jamaican children's representations of tourism. Annals of Tourism Research, 22(4), 735-762.

Gibson, J. E. (2012). Interviews and focus groups with children: Methods that match children's developing competencies. Journal of Family Theory \& Review, 4(2), 148-159. doi:10.1111/j.1756-2589.2012.00119.x

Gram, M. (2007). Children as co-decision makers in the family? The case of family holidays. Young Consumers: Insight and Ideas for Responsible Marketers, 8(1), 19-28. doi:10.1108/17473610710733749

Gram, M., \& Therkelsen, A. (2003). Børnefamileferie: Family Holiday, report about family holiday content, decision-making processes and perceptions of Denmark as a holiday destination. Retrieved from Aalborg, Denmark:

Gross, J., \& Hayne, H. (1998). Drawing facilitates children's verbal reports of emotionally laden events. Journal of Experimental Psychology: Applied, 4(2), 163- 179. doi:10.1037/1076-898X.4.2.163

Hilbrecht, M., Shaw, S. M., Delamere, F. M., \& Havitz, M. E. (2008). Experiences, perspectives, and meanings of family vacations for children. Leisure/Loisir, 32(2), 541571. doi:10.1080/14927713.2008.9651421

Howard, D. R., \& Madrigal, R. (1990). Who makes the decision: The parent or the child? The perceived influence of parents and children on the purchase of recreation services. Journal of Leisure Research, 22(3), 244-258.

Hsieh, Y. J., \& Scammon, D. L. (2015). The Role of Chinese Culture in International Marketing. Paper presented at the Proceedings of the 1993 Academy of Marketing Science (AMS) Annual Conference.

Khoo-Lattimore, C. (2015). Kids on board: methodological challenges, concerns and clarifications when including young children's voices in tourism research. Current Issues in Tourism, 18(9), 845-858. doi:10.1080/13683500.2015.1049129

Khoo-Lattimore, C., \& Mura, P. (2016). Asian Genders in Tourism. Bristol, UK: Channel View Publications.

Khoo-Lattimore, C., \& Prayag, G. (2015). The girlfriend getaway market: Segmenting accommodation and service preferences. International Journal of Hospitality Management, 45, 99-108. doi:10.1016/j.ijhm.2014.12.003

Khoo-Lattimore, C., Prayag, G., \& Cheah, B. L. (2015). Kids on board: Exploring the choice process and vacation needs of asian parents with young children in resort hotels. Journal of Hospitality Marketing \& doi:http://dx.doi.org/10.1080/19368623.2014.914862

Khoo-Lattimore, C., Yang, E. C. L., \& Lai, M. Y. (2016). Comparing the Meanings of Food in Different Chinese Societies: The Cases of Taiwan and Malaysia. Journal of Hospitality Marketing \& Management, 1-21. doi:10.1080/19368623.2016.1156042

Kim, S. S., Choi, S., Agrusa, J., Wang, K.-C., \& Kim, Y. (2010). The role of family decision makers in festival tourism. International Journal of Hospitality Management, 29(2), 308-318.

Kluin, J. Y., \& Lehto, X. Y. (2012). Measuring family reunion travel motivations. Annals of Tourism Research, 39(2), 820-841. 
Kuhn, P. (2003). Thematic drawing and focused, episodic interview upon the drawing: A method in order to approach to the children's point of view on movement, play and sports at school. Forum: Qualitative Social Research, 4(1), 1-16.

Kwek, A., \& Lee, Y. S. (2010). Chinese tourists and Confucianism. Asia Pacific Journal of Tourism Research, 15(2), 129-141.

Lee, C. K.-C., Wong, M. Y., \& Brown, R. (2015). A Preliminary Study on the Influence of the Confucian Dynamism on Family Decision Making. Paper presented at the Proceedings of the 1997 World Marketing Congress.

Lehto, X. Y., Choi, S., Lin, Y.-C., \& MacDermid, S. M. (2009). Vacation and family functioning. Annals of Tourism Research, 36(3), 459-479. doi:10.1016/j.annals.2009.04.003

Liang, Y.-W. (2013). Children's influence on purchasing tourism products via the internet: Parental power versus children's power-the social power perspective. Journal of Travel \& Tourism Marketing, 30(7), 639-661. doi:10.1080/10548408.2013.827543

Lugosi, P., Robinson, R. N., Golubovskaya, M., \& Foley, L. (2016). The hospitality consumption experiences of parents and carers with children: A qualitative study of foodservice settings. International Journal of Hospitality Management, 54, 84-94.

Malaysian Parents Choose International Schools Over National Schools These Days - What Are The Advantages? (2015). Retrieved from http://www.malaysiandigest.com/opinion/554189-malaysian-parents-chooseinternational-schools-over-national-schools-these-days-what-are-the-advantages.html

March, R. (1997). Diversity in Asian outbound travel industries: a comparison between Indonesia, Thailand, Taiwan, South Korea and Japan. International Journal of Hospitality Management, 16(2), 231-238.

Mitchell, L. M. (2006). Child-centered? Thinking critically about children's drawings as a visual research method. Visual Anthropology Review, 22(1), 60-73. doi:10.1525/var.2006.22.1.60

Mok, C., \& DeFranco, A. L. (2000). Chinese cultural values: Their implications for travel and tourism marketing. Journal of Travel and Tourism Marketing, 8(2), 99-114.

Mura, P., \& Khoo-Lattimore, C. (2018). Locating Asian research and selves in qualitative tourism research Asian Qualitative Research in Tourism. Singapore: Springer.

Mura, P., \& Pahlevan Sharif, S. (2015). The crisis of the 'crisis of representation'-mapping qualitative tourism research in Southeast Asia. Current Issues in Tourism, 1-17. doi:10.1080/13683500.2015.1045459

Murray, L. (2015). Age-friendly mobilities: A transdisciplinary and intergenerational perspective. Journal of Transport \& Health, 2(2), 302-307.

Ngai, E. W., Heung, V. C., Wong, Y., \& Chan, F. K. (2007). Consumer complaint behaviour of Asians and non-Asians about hotel services: An empirical analysis. European Journal of Marketing, 41(11/12), 1375-1391.

Nickerson, N. P., \& Jurowski, C. (2001). The influence of children on vacation travel patterns. Journal of Vacation Marketing, 7(1), 19-30. doi:10.1177/135676670100700102

Poria, Y., \& Timothy, D. J. (2014). Where are the children in tourism research? Annals of Tourism Research, 47, 93-95. doi:10.1016/j.annals.2014.03.002

Reisinger, Y., \& Turner, L. W. (2002). Cultural differences between Asian tourist markets and Australian hosts, Part 1. Journal of Travel Research, 40(3), 295-315.

Ruff, H. A., \& Lawson, K. R. (1990). Development of sustained, focused attention in young children during free play. Developmental psychology, 26(1), 85-93. doi:10.1037/00121649.26.1.85 
Schänzel, H. A. (2012). The inclusion of fathers, children and the whole family group in tourism research on families. In H. Schänzel, I. Yeoman, \& E. Backer (Eds.), Family tourism: Multidisciplinary perspectives (pp. 67-80). Bristol, UK: Channel View.

Schänzel, H. A., \& Smith, K. A. (2014). The socialization of families away from home: Group dynamics and family functioning on holiday. Leisure Sciences: An Interdisciplinary Journal, 36(2), 126-143. doi:10.1080/01490400.2013.857624

Schänzel, H. A., \& Yeoman, I. (2015). Trends in family tourism. Journal of Tourism Futures, 1(2), 141-147.

Schänzel, H. A., Yeoman, I., \& Backer, E. (Eds.). (2012). Family tourism: Multidisciplinary perspectives. Bristol, UK: Channel View.

Segumpan, R. G., Zahari, J. S. A., \& Jamaluddin, M. M. (2008). Tourism among Families in Northern Peninsular Malaysia. Asia-Pacific Social Science Review, 8(2), 129-139.

Small, J. (2008). The absence of childhood in tourism studies. Annals of Tourism Research, 35(3), 772-789. doi:10.1016/j.annals.2008.06.002

Therkelsen, A. (2010). Deciding on family holidays - role distribution and strategies in use. Journal of Travel \& Tourism Marketing, 27(8), 765-779.

Thornton, P. R., Shaw, G., \& Williams, A. M. (1997). Tourist group holiday decision-making and behaviour: The influence of children. Tourism Management, 18(5), 287-297. doi:10.1016/S0261-5177(97)00017-4

Todd Weaver, S., Moschis, G. P., \& Davis, T. (2011). Antecedents of materialism and compulsive buying: A life course study in Australia. Australasian Marketing Journal, 19(4), 247-256.

Tse, T. S. M., \& Hobson, J. S. P. (2008). China's outbound tourism as a way of ordering. Journal of China Tourism Research, 7(4), 490-505.

Tucker, H., \& Zhang, J. (2016). On Western-centrism and" Chineseness" in tourism studies. Annals of Tourism Research, 61, 250-252.

Turley, S. K. (2001). Children and the demand for recreational experiences: The case of zoos. Leisure Studies, 20(1), 1-18. doi:10.1080/02614360122877

UNWTO. (2016). UNWTO Tourism Highlights, 2016 Edition. Retrieved from Madrid:

Wang, K.-C., Hsieh, A.-T., Yeh, Y.-C., \& Tsai, C.-W. (2004). Who is the decision-maker: the parents or the child in group package tours? Tourism Management, 25(2), 183-194.

Watkins, L., Aitken, R., Robertson, K., Thyne, M., \& Williams, J. (2016). Advertising's impact on pre-schoolers' brand knowledge and materialism. International Journal of Consumer Studies, 40(5), 583-591.

Weaver, D., Becken, S., Ding, P., Mackerras, C., Perdue, R., Scott, N., \& Wang, Y. (2015). Research Agenda for Tourism and the Chinese Dream Dialogues and Open Doors. Journal of Travel Research, 54(5), 578-583.

Wong. (1996). A study of educational value in a theme park with reference to a case study of Ocean Park. (Bachelors Dissertation), Hong Kong Polytechnic University, Hong Kong.

Yang, E. C. L., Khoo-Lattimore, C., \& Arcodia, C. (2016). A narrative review of Asian female travellers: looking into the future through the past. Current Issues in Tourism, 1-20. doi:10.1080/13683500.2016.1208741

Yang, E. C. L., Khoo-Lattimore, C., \& Arcodia, C. (2017). Constructing space and self through risk taking: A case of Asian solo female travelers. Journal of Travel Research. doi: $10.1177 / 0047287517692447$

Yang, E. C. L., Lee, J. S. H., \& Khoo-Lattimore, C. (2018). Asian Cultures and Contemporary Tourism: Locating Asia, Cultural Differences and Trends In C. L. Yang \& C. KhooLattimore (Eds.), Asian Cultures and Contemporary Tourism. Singapore: Springer. 